\title{
Review of Molecular Modeling of Clays and Mineral Surfaces
}

\author{
(CMS workshop lectures, Volume 12), edited by J.D. Kubicki and W.F. Bleam
}

(The Clays Minerals Society, Aurora, CO) 2003.

\author{
by Eric Cockayne \\ Ceramics Division, NIST, Gaithersburg, MD 20899
}

\begin{abstract}
Many issues in environmental science require understanding the interaction between soils, water, and sediments. For example, the containment of radioactive or chemical wastes is related to the ability of the constituent soil materials to chemically bind these materials. As available computational power has grown in recent years, molecular modeling has become an important tool in the field. This book gives an overview of state-of-the art methods and results in using molecular modeling to investigate the interaction of clay and mineral surfaces with water and with water containing solvents.

Chapter 1 gives an overview of molecular modeling methods. Different methods are preferred for different length scales. For systems containing tens of atoms, fully quantum mechanical solution of the electronic structure problem is preferred. For larger systems (generally including systems large enough to model the interaction of water and solutes with surfaces), empirical "force field" methods are preferred. The advantages and disadvantages of each method are discussed, as well as how hardware considerations affect the size of the system that can be practically simulated. The description of various packages available for molecular simulations will be useful to those wishing to incorporate molecular modeling into their research.

The subsequent chapters are devoted to the use of molecular modeling to investigate specific problems involving mineral surfaces and sorption. Chapter 2 discusses electronic structure methods for treating the interfaces between mineral surfaces and water. In chapters 3 and 4 , force-field models
\end{abstract}

are used to study the interaction of water and aqueous ions with clay surfaces. Chapter 5 presents a more abstract model, designed for the larger-length scale problem of how metal ions bind with chemically heterogeneous soil materials. These chapters discuss the power of molecular modeling to predict structure, thermodynamics, preferred binding sites, the dynamics of ion diffusion and binding, and the effects of $\mathrm{pH}$ on sorption.

Several common themes run through this volume. The importance of first understanding existing experimental results before making predictions is emphasized. Furthermore, modeling should not be done independently of, or thought of a replacement for experiments, but, in fact, even more experiments are necessary, not only to confirm the modeling predictions, but also to provide necessary inputs for better models. Technical difficulties involved in modeling surfaces realistically are discussed. Finally, it is pointed out that it is still computationally expensive to get good agreement with experiments in many cases.

The faults of this book are some minor errors, oversimplification in the discussion of statistical mechanics and electronic structure methods in places, and the use of jargon and symbols that are not familiar except to specialists. Still, it provides a good overview for those who may wish to become more familiar with modeling the interactions of aqueous solutions with mineral surfaces, and leaves one with the hope that a combination of experimental and modeling methods will provide new solutions to related environmental and industrial problems.

\section{Calendar of Meetings}

\author{
Donald R. Petersen \\ Greenleaf Associates \\ 6210 Siebert Street \\ Midland, MI 48640-2724, USA \\ drpetersen@tm.net
}

\section{6-7 December 2004}

Micro- and Mesoporous Mineral Phases. Rome, Italy. Organized by the IUCr Commission on Inorganic and Mineral Structures and the Accademia Nazionale dei Lincei. To include mineralogical, crystallographic, and technological aspects of these materials. [Contact: Info: http://lcm3b.uhpnancy.fr/cims/micromesoporous.htm].

\section{3-17 February 2005}

Neutron Diffraction Characterization of Mechanical Behavior. San Francisco, California, USA. A symposium to be held during the 134th TMS Annual Meeting \& Exhibition. [Contact: TMS Meeting Services, 184 Thorn Hill Road, Warrendale, PA 15086, USA. Tel: 1 (764) 7769000 ext 243; Fax: 1 (764) 776 3700; E-mail: mtgserv@tms.org; Info: http:// www.tms.org/Meetings/Annual-05/AnnMtg05Home.html].

\section{4-18 February 2005}

Australian X-ray Analytical Association 2005 Conference and Exhibition. Perth, Western Australia, Australia. [Contact: Dr. Brian O'Connor, Curtin University, GPO Box U1987, Perth, WA 6001, Australia, toconnorb@ 
cc.cutin.edu.au or Tulips Meeting Management, Post Office Box 116, Salamander Bay, NSW 2317, Australia. Tel: 61 (2) 4984 2554; Fax: $61 \quad$ (2) 4984 2755; E-mail: axaa@pco.com.au; Info: http://www.pco.com.au/axaa2005].

\section{4-18 March 2005}

International Centre for Diffraction Data, Spring Meeting. Newtown Square, Pennsylvania, USA. [Contact: Linda Shertz, International Centre for Diffraction Data, 12 Campus Boulevard, Newtown Square, PA 19073-3273, USA. Tel: 1 (610) 325 9814; Fax: 1 (610) 325 9823; E-mail: shertz@icdd.com; Info: http://www.icdd.com].

\section{March-1 April 2005}

Materials Research Society Spring Meeting. San Francisco, California, USA. [Contact: Materials Research Society, 506 Keystone Drive, Warrendale, PA 15086-7573, USA. Tel: 1 (724) 779 3003; Fax: 1 (724) 779 8313; E-mail: info@mrs.org; Info: http://www.mrs.org].

\section{0-13 April 2005}

107th Annual Meeting and Exposition of The American Ceramic Society. Baltimore, Maryland, USA. [Contact: The American Ceramic Society, 735 Ceramic Place, Westerville, OH 43081, USA. Tel: 1 (614) 794 5890; Fax: 1 (614) 794 5892; E-mail: info@ceramics.org; Info: http:// www.ceramics.org/meetings].

\section{2-14 April 2005}

British Crystallographic Association Annual Spring Meeting. Loughborough, England, United Kingdom.

\section{May-2 June 2005}

American Crystallographic Association Annual Meeting. Orlando, Florida, USA. [Contact: Khalil Abboud at abboud@chem.ufl.edu; Ed Collins at edward_collins@ med.unc.edu; Info: http://www.hwi.buffalo.edu/ACA].

\section{June-1 July 2005}

Joint 20th AIRAPT-43rd EHPRG International Conference on High Pressure Science and Technology. Karlsruhe, Germany. Associated with the 7th EMU School in Mineral Behaviour at Extreme Conditions in Heidelberg, 19-28 June. [Contact: Prof. Dr. Eckhard Dinjus, Forschungszenrum Karlsruhe (ITC-CPV), PO Box 3640, D-76021 Karlsruhe, Germany. Tel: 49 (7247) 8224 00; Fax: 49 (7247) 8224 44; Info: http://hikwww2.fzk.de/ehprg].
1-5 August 2005

54th Annual Denver X-ray Conference. Colorado Springs, Colorado, USA. [Contact: Denise Flaherty, International Centre for Diffraction Data, 12 Campus Boulevard, Newtown Square, PA 19073-3273, USA. Tel: 1 (610) 325 9814; Fax: 1 (610) 325 9823; E-mail: flaherty@icdd.com; Info: http://www.dxcicdd.com].

\section{3-31 August 2005}

20th IUCr General Assembly and International Congress of Crystallography. Florence, Italy. [Contact: Congress Secretariat, XX Congress IUCr, Dipartimento di Energetica, Università di Firenze, via S. Marta 3, 50139 Firenze, Italy. Tel: 39 (055) 479 6240; Fax: 39 (055) 479 6342; E-mail: iucr@iucr2005.it; Info: http://www.iucr2005.it].

\section{9-13 October 2005}

32nd Annual Conference of the Federation of Analytical Chemistry and Spectroscopy Societies (FACSS). Quebec, Canada. [Contact: FACSS, Post Office Box 24379, Santa Fe, NM 87502, USA. Tel: 1 (505) 820 1648; Fax: 1 (505) 989 1073; E-mail: facss@facss.org; Info: http://www.facss.org].

28 November-2 December 2005

International Conference on Neutron Scattering. Sydney, Australia. [Contact: Brendan Kennedy, School of Chemistry, Building F11, University of Sydney, Sydney, NSW 2006, Australia. E-mail: b.kennedy@chem.usyd.edu.au; Info: http://www.sct.gu.edu.au/icns2005].

\section{Summer 2006}

23rd European Crystallographic Meeting. Leuven, Belgium.

\section{6-23 July 2006}

7th International Conference on the Occurrence, Properties, and Utilization of Natural Zeolites. Socorro, New Mexico, USA. [Contact: Robert Bowman, New Mexico Institute of Technology, Socorro, New Mexico, USA. E-mail: bowman@nmt.edu].

\section{Summer 2008}

21st IUCr General Assembly and International Congress of Crystallography. Osaka, Japan.

\section{Short Courses \& Workshops}

\section{1-4 December 2004}

Fifth International School of Crystallography and Diffraction. Havana, Cuba. [Contact: Dr. Ernesto Estevez Rams, Instituto de Materiales y Reactivos, Universidad de La Habana, Zapata y G., CP: 10400, Ciudad de La Habana, Cuba. Tel: 53 (7) 870 7666; Fax: 53 (7) 879 4651; Info: http://www.cristalografia.net/home_en.htm].

\section{1-24 February 2005}

PPXRD-4 Pharmaceutical Powder X-ray Diffraction Symposium. Barcelona, Spain. [Contact: Leah Mooney, Education Coordinator, International Centre for Diffraction Data, 12 Campus Boulevard, Newtown Square, PA 190733273, USA. Tel: 1 (610) 325 9814; Fax: 1 (610) 325 9823; E-mail: ppxrd@icdd.com; Info: http://www.icdd.com/ppxrd]. 